\title{
Workers, Firms and Task Heterogeneity in International Trade Analysis: An Example of Wage Effects of Trade Within GVC
}

\author{
Aleksandra Parteka, Joanna Wolszczak-Derlacz
}

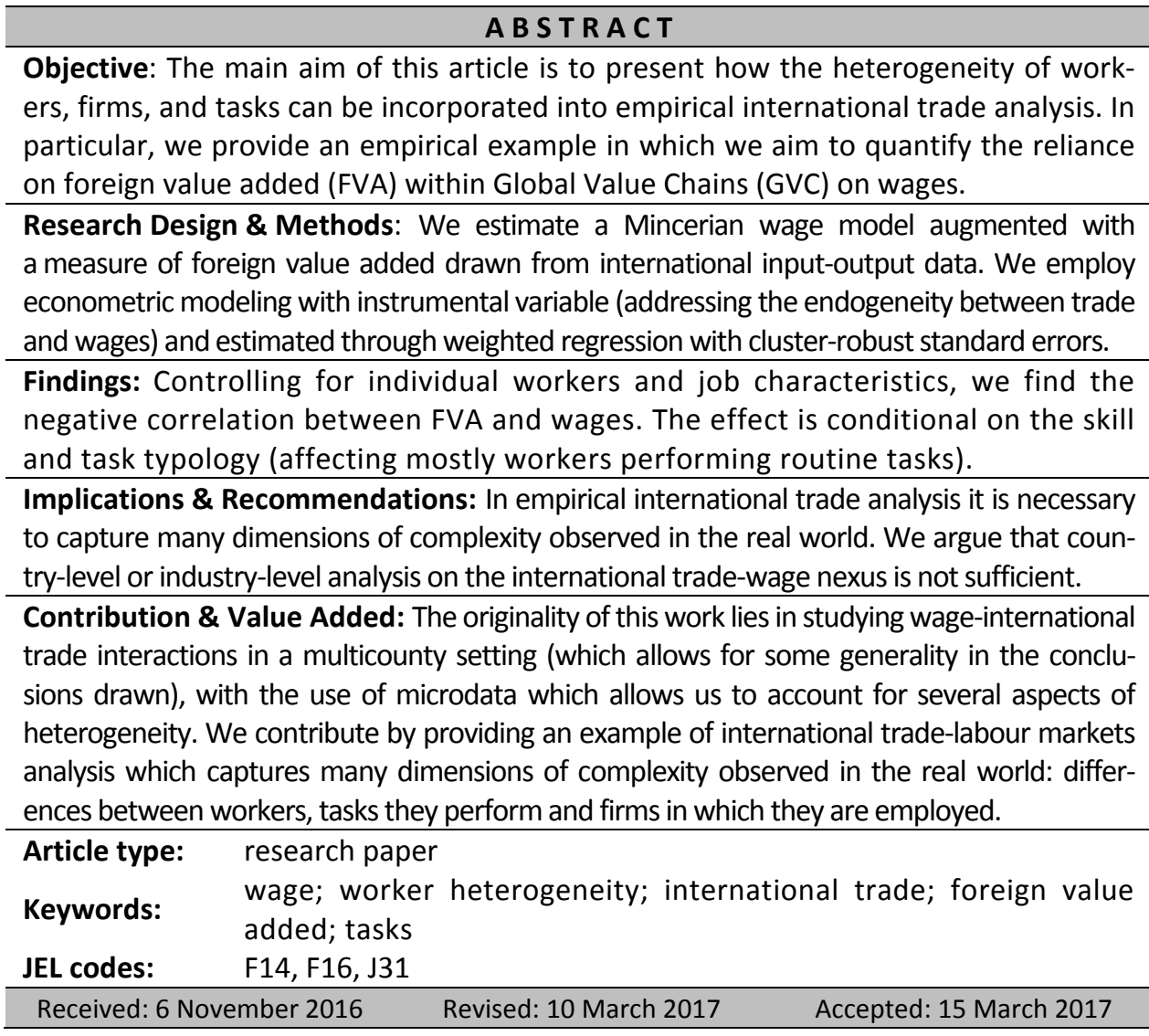

\section{Suggested citation:}

Parteka, A., \& Wolszczak-Derlacz J. (2017). Workers, Firms and Task Heterogeneity in International Trade Analysis: An Example of Wage Effects of Trade Within GVC. Entrepreneurial Business and Economics Review, 5(2), 9-25, DOI: http://dx.doi.org/10.15678/EBER.2017.050201 


\section{INTRODUCTION}

Among the key topics present in the recent international trade literature we can notice a general shift towards an analysis which tries to be as close as possible to the real life situations. Following the seminal contribution of Melitz (2003), the so-called 'new-new trade theory' which takes into account firm heterogeneity has become a new reference point in international trade analysis ${ }^{1}$. The heterogeneity of workers and tasks they perform (Autor, 2013) is also present in several streams of international trade analysis, and especially in contributions dealing with labour market effects of increasing trade integration. As noted by Grossman (2013), the heterogeneity of labour has to be taken into consideration when analysing such topics such as skill dispersion as a source of comparative advantage or how globalisation affects the distribution of wages and unemployment across different types of workers.

The main objective of this article is to show how the heterogeneity of workers, firms, and tasks can be incorporated into empirical international trade analysis. In particular, we provide an empirical example in which we focus on quantifying the effects of trade within the so-called Global Value Chains (from now on GVC ${ }^{2}$ - Los, Timmer \& Vries, 2015) on wages. We consider the effect of trade within GVC on workers differing in terms of personal characteristics, skills, performed tasks or firms in which they are employed. This topic is important not only from scientific perspective per se, but the examination of labour effects of GVC's expansion is of high policy relevance (i.e. potential uneven distribution of gains from international production fragmentation).

The originality of this work lies in studying wage-international trade interactions in a multicounty setting, with the use of microdata which allows us to account for several aspects of heterogeneity. We contribute by providing an example of international tradelabour markets analysis which captures many dimensions of complexity observed in the real world: differences between workers, tasks they perform and firms in which they are employed. As main method of analysis, we employ an econometric model with an instrumental variable (addressing the endogeneity between trade and wages) and estimated through weighted regression with cluster-robust standard errors.

The paper is structured as follows. In Section 2 we describe the related literature on international trade-labor market interactions which takes into account heterogeneity of firms, workers and tasks they perform. Section 3 is dedicated to the data and methods used in our empirical analysis. Section 4 presents the results of econometric estimation and, finally, Section 5 concludes and presents the main direction for further research.

\footnotetext{
${ }^{1}$ Melitz and Redding (2014) provide an excellent review of the related literature on hetereogenous firms and trade. Wagner (2012) surveys empirical studies on international trade and firm performance which have built upon the Melitz approach. Theory of international trade is thoroughly presented in Feenstra (2016), also with respect to the role of heterogenous firms in shaping trade patterns and the gains from trade.

${ }^{2}$ GVC and corresponding international input-output matrices are useful in describing the process of fragmentation of production chains across borders. In international trade data this process is visible though the networks of intermediate input flows between countries. For a recent survey on GVC drivers and measures see Amador and Cabral (2016).
} 


\section{LITERATURE REVIEW}

\section{International Trade Literature Allowing for Heterogeneity of Firms, Tasks, and Workers}

Heterogeneity of workers is discussed in many influential papers dealing with international trade modeling. Melitz (2003) was the first to address theoretically across firms differences in productivity which help to explain their varying involvement in the export activity. His theoretical approach (the so-called 'Melitz model') contributed to explaining a variety of features observed in disaggregated trade data, including the higher productivity of exporters relative to non-exporters, within-industry reallocations of resources following trade liberalization, and patterns of trade participation across firms and destination markets. Yeaple (2005) introduced a general equilibrium trade model in which homogeneous firms choose a technology from a set of competing technologies and choose employees from a set of workers of heterogeneous skills. He provides a theoretical explanation for the effect of international trade on the skill premium and observed industry-level productivity. The model of international trade with heterogeneous firms by Helpman, Melitz and Rubinstein (2008) predicts positive as well as zero trade flows across pairs of countries, and allows the number of exporting firms to vary across destination countries. Grossman and Rossi-Hansberg (2008) develop a very influential theoretical framework in which the effects of offshoring on wages, employment, and productivity heavily depend on the nature of performed tasks ${ }^{3}$. Only some of the tasks can be offshored. Amiti and Davis (2012) provide a model to explain how the impact of final and intermediate input tariff cuts on workers' wages varies with the global engagement of their firm. Their model predicts that a fall in output tariffs lowers wages at import-competing firms but increases wages at exporting firms. Overall, all of these contributions (and many others) attempted to bring the theory of international trade and its effects as close to the reality as possible.

Given the empirical nature of our paper, we shall focus on recent empirical contributions in the field. In general, our study can be positioned within the literature on trade - labour markets nexus. Since the 1990s it has been a widely studied topic, especially from a potential threat that trade liberalisation with less developed (and thus lower wage) countries can pose a threat to workers in developed countries (early contributions include, among others: Wood, 1995; Freeman, 1995). Recent literature based on microdata seems to focus on estimating the effects of increasing trade in parts and components and offshoring on workers (the term 'offshoring jobs' has been coined by Harrison and McMillan, 2011). The case of increasing import competition from China or other developing countries on American workers has been widely studied (e.g. Hanson et al., 2013; Ebenstein, Harrison, McMillan \& Phillips, 2014; Autor et al., 2014). Similar analysis was performed with respect to the effects exhibited on workers from other well-developed countries such as Denmark (Hummels, Jorgensen, Munch \& Xiang, 2014), Germany (Baumgarten, Geishecker \& Gorg, 2013; Dauth et al., 2014) or the UK (Geishecker \& Görg, 2013).

\footnotetext{
${ }^{3}$ This approach has been developed by Baldwin and Robert-Nicoud (2014) who integrated trade-in-goods and trade-in-tasks within one theoretical framework.
} 
Related empirical analysis adopting micro level data and multicountry perspective (and thus allowing for a broader cross-country view) is much more scarce. Our paper can be viewed as an attempt to contribute to this stream of literature. The exceptions include Geishecker, Görg and Munch (2010) on wage effects of outsourcing in Germany, UK, and Denmark or Goos, Manning and Salomons (2014) who use the microdata to classify workers according to the tasks they perform and to describe the process of job polarization ${ }^{4}$ in 16 European countries.

\section{The Development of Literature on Methods of Firms', Workers' and Tasks' Heterogeneity Measurement}

The measurement of firm heterogeneity is relatively simple - as surveyed in Wagner (2012) most of the empirical papers have focused on differentials in terms of firms' productivity, size or industry of activity (public versus private). In their review paper, Bernard, Jensen, Redding and Schott (2012) individuate that covering these aspects of firm's heterogeneity in empirical international trade analysis allows to explore such dimensions as: multiproduct firms, offshoring, intrafirm trade and firms' export market dynamics.

Workers heterogeneity means primarily the need to use microlevel (i.e. worker specific) data on wages or employment in a setting in which additional information on personal characteristics of workers is also available. For instance, by doing so, wage pattern can be explained as a function of worker's age, sex, experience, education or family status (such a Mincer equation is comprehensively described in Heckman, Lochner and Todd 2006). In an analysis on wage effects of trade the augmented Mincerian model is often used. Personal characteristics of workers are matched with industry-level data on the characteristics of industries in which these workers are employed. This is the approach we follow in our study, but we also incorporate newer methods of task content measurement plus the decomposition of trade according to the source of the employed value added.

Traditionally, workers were classified as skilled or unskilled, and such information was based upon the data on their education (see e.g. Wolszczak-Derlacz \& Parteka, 2016). However, recent literature underlines the importance of a proper distinction between skills and tasks (Autor, 2013). As Grossman and Rossi-Hansberg (2008) suggested in their theoretical framework of 'trade-in-tasks,' the effects of offshoring depend on the cost of trading, which may differ across different types of tasks. Hence, the literature seems to go into the direction of even deeper classification of workers by taking into account precise information on the tasks they perform within their occupations. The information on the occupation of single workers is typically available in micro datasets, hence the aim is to map the occupation with a particular type of tasks. Such an exercise has been performed by Autor and Dorn (2013), Autor, Dorn and Hanson (2015) or Goos, Manning and Salomons (2014) who computed Routine Task Intensity index for occupations at the ISCO 2-digit level. Using this index's occupations (and, hence, workers) can be classified into groups which differ in terms of routine, abstractness and service task importance. On the basis of this information, it is possible to individuate tasks which are 'offshorable.' Originally, Autor and Dorn (2013) drew on the US information on abstract,

\footnotetext{
${ }^{4}$ They attribute it to so-called routine biased technological change (RBTC). According to RBTC hypothesis the technology can replace human labour in routine tasks.
} 
routine and manual tasks based on data from the Dictionary of Occupational Titles while their measure of offshore ability was based on task values from $\mathrm{O} * \mathrm{Net}^{5}$.

Such methods of task content measurement allow for a very precise analysis of the changing labor markets' structure and their interaction with trade integration and offshoring. Recently, task measures from $\mathrm{O}^{*}$ Net were employed for instance by Fortin and Lemieux (2016). They document substantial changes in both the within and between dimensions of occupational wages over time and find that these changes are well described by changes in task prices induced by technological change and offshoring. Becker and Muendler (2015) provided an interesting study in which they combined German worker-level data that cover time-varying job-level task characteristics of an economy over several decades (1979-2006) with industry-level bilateral trade data for merchandise and services. Their approach allows them to uncover that the German workforce increasingly specializes in workplace activities and job requirements that are typically considered non-offshorable; while the imputed activity and job requirement content of German imports grows relatively more intensive in work characteristics typically considered offshorable. Cortes (2016) uses a similar method to document wage polarization and routine-biased technical change.

We shall rely on Goos et al. (2014) method of task classification in our work.

\section{MATERIAL AND METHODS}

The Data

In our study, we match microlevel and industry level data. Luxembourg Income Study (LIS) is our most important source of microlevel data on workers - their wage, personal characteristics or family status. Information on firms in which these workers are employed (industry of activity, status: public versus private, size ${ }^{6}$ ) also comes from LIS $^{7}$. Industry level data comes from WIOD (World Input-Output Database described in Timmer, Dietzenbacher, Los, Stehrer \& Vries, 2015). In particular, as an indicator of reliance on imported inputs, we will use the information on foreign value added employed in the domestic industry. It is obtained through Wang, Wei and Zhu, (2013)'s decomposition performed on WIOD's data with the use of Quast and Kummritz (2015) decompr package in $\mathrm{R}^{8}$.

In our dataset, we have the data for workers from 14 countries (listed in Table 2) and employed in 34 industries. The list of variables used in our analysis, along with their description and sources, is provided in Table 1.

\footnotetext{
${ }^{5}$ O*Net (Occupational Information Network) dataset is provided by the United States Department of Labour and is a source of occupational task-intensity data. O*NET measures the importance of various physical (dexterity, coordination, strength) and language (oral and written comprehension and expression) abilities within each occupation code. Data values are based upon experts' assessments and reflect the use of skills across occupations.

${ }^{6}$ Original datasets from LIS for some of the countries do not provide more specific information on the number of employees in a firm. Hence, in controlling for firm size in our multicountry setting we are constrained to adopt small/big firms classification - is it not possible to account for traditional 10, 50, 250, 500 - workers thresholds.

${ }^{7}$ The data was accessed during an onsite visit to LIS premises in Luxembourg. We used wave 8 data corresponding to the year 2010.

${ }^{8}$ The decomposition was used among others by Olczyk and Kordalska (2016).
} 
In Table 2 we show the differences in our dependent variable - gross hourly wage - across countries and workers. Mean wage is the lowest in Mexico (only 2.8 USD per hour) while the highest in Luxembourg (33.4 USD), so cross-country differences are enormous (the data refers to 2010). Unsurprisingly, in all of the countries workers with the highest educational level completed (university education) are paid better than those with secondary or primary education (medium and low category). Employees performing routine tasks have lower wages.

Table 1. List of variables used in the analysis

\begin{tabular}{|c|c|c|}
\hline Variables & Definition & $\begin{array}{c}\text { Source } \\
\text { (the code of variable } \\
\text { in the dataset) }\end{array}$ \\
\hline \multirow{3}{*}{$\begin{array}{l}\text { gross hourly } \\
\text { wage* =annual } \\
\text { earnings/ (an- } \\
\text { nual weeks } \\
\text { worked ×weekly } \\
\text { hours worked) }\end{array}$} & $\begin{array}{l}\text { earnings - monetary payments and the value of } \\
\text { non-monetary goods and services received from } \\
\text { regular and irregular dependent employment }\end{array}$ & $\begin{array}{l}\text { LIS } \\
\text { (pile) }\end{array}$ \\
\hline & $\begin{array}{l}\text { annual weeks worked - the number of weeks } \\
\text { worked during the year in any job }\end{array}$ & $\begin{array}{l}\text { LIS } \\
\text { (weeks) }\end{array}$ \\
\hline & $\begin{array}{l}\text { weekly hours worked - regular hours worked at all } \\
\text { jobs currently held }\end{array}$ & $\begin{array}{l}\text { LIS } \\
\text { (hours) }\end{array}$ \\
\hline \multirow{6}{*}{$\begin{array}{l}\text { Personal char- } \\
\text { acteristics }\end{array}$} & sex & LIS (Sex) \\
\hline & age in years & LIS (Age) \\
\hline & $\begin{array}{l}\text { education level (highest completed). According to } \\
\text { ISCED levels: high education - ISCED } 5 \text { or } 6 \text {, medi- } \\
\text { um - ISCED } 3 \text { or } 4 \text {, low - ISCED } 0,1 \text { or } 2\end{array}$ & $\begin{array}{l}\text { LIS } \\
\text { (Educ) }\end{array}$ \\
\hline & marital status - married or in union & LIS (marital) \\
\hline & partner - living with a partner & LIS (partner) \\
\hline & $\begin{array}{l}\text { children - living with children (biological, adoptive } \\
\text { or step) }\end{array}$ & $\begin{array}{l}\text { LIS } \\
\text { (children) }\end{array}$ \\
\hline \multirow{5}{*}{$\begin{array}{l}\text { Firm/job char- } \\
\text { acteristic }\end{array}$} & $\begin{array}{l}\text { part time - working part-time or less than } 30 \\
\text { hours per week }\end{array}$ & $\begin{array}{l}\text { LIS } \\
\text { (ptime) }\end{array}$ \\
\hline & $\begin{array}{l}\text { the size of the company - the number of individu- } \\
\text { als employed in the local unit* }\end{array}$ & $\begin{array}{l}\text { LIS } \\
\text { (NEMP) }\end{array}$ \\
\hline & private or public industry of employment* & LIS (SECT) \\
\hline & $\begin{array}{l}\text { multiple jobs holder - an indicator of multiple } \\
\text { simultaneous jobs for employed individuals }\end{array}$ & $\begin{array}{l}\text { LIS } \\
\text { (SECJOB) }\end{array}$ \\
\hline & $\begin{array}{l}\text { occupational classification of the first job, based } \\
\text { on the ten major groups of ISCO classification }\end{array}$ & $\begin{array}{l}\text { LIS } \\
(\mathrm{OCCB})\end{array}$ \\
\hline $\begin{array}{l}\text { Task character- } \\
\text { istics }\end{array}$ & $\begin{array}{l}\text { task typology according to the type of tasks mainly } \\
\text { used in the given occupation }\end{array}$ & Goos et al. (2014) \\
\hline \multirow{3}{*}{$\begin{array}{l}\text { Industry charac- } \\
\text { teristics }\end{array}$} & $\begin{array}{l}\text { industry - manufacturing, services, agriculture, } \\
\text { construction, mining }\end{array}$ & WIOD (code) \\
\hline & industry size - value added & WIOD (VA) \\
\hline & $\begin{array}{l}\text { dependence on foreign value added - obtained } \\
\text { from the export decomposition }\end{array}$ & $\begin{array}{l}\text { WIOD (FVA) + Wang } \\
\text { et al. (2013) }\end{array}$ \\
\hline
\end{tabular}

Note:* available for the limited number of countries, the missing values were assigned using the Gaussian normal regression imputation method.

Source: own elaboration based on LIS and WIOD. 
Table 2. Variability of hourly wage across countries in our sample - heterogeneity in workers' education and performed tasks

\begin{tabular}{|c|c|c|c|c|c|c|}
\hline \multirow{2}{*}{ country } & \multirow{2}{*}{ mean } & \multicolumn{3}{|c|}{ Education level of workers } & \multicolumn{2}{c|}{ Tasks performed by workers } \\
\cline { 3 - 7 } & & high & medium & low & non-routine & routine \\
\hline CZE & 6.9 & 9.7 & 6.3 & 4.6 & 8.6 & 6.1 \\
\hline EST & 6.3 & 8.3 & 5.3 & 5.4 & 7.9 & 5.8 \\
\hline FIN & 25.5 & 29.7 & 21.8 & 21.2 & 30.3 & 21.6 \\
\hline FRA & 23.0 & 31.9 & 19.1 & 15.5 & 31.4 & 18.2 \\
\hline DEU & 23.8 & 32.0 & 20.4 & 17.2 & 29.3 & 20.0 \\
\hline GRC & 13.9 & 17.3 & 11.9 & 10.5 & 17.9 & 11.8 \\
\hline IRL & 29.1 & 34.6 & 23.3 & 22.9 & 36.3 & 23.8 \\
\hline LUX & 33.4 & 47.8 & 31.7 & 22.1 & 44.5 & 24.1 \\
\hline MEX & 2.8 & 5.7 & 2.9 & 1.7 & 4.6 & 2.1 \\
\hline SVK & 5.6 & 7.0 & 5.1 & 3.8 & 6.5 & 5.2 \\
\hline SVN & 9.4 & 12.2 & 8.1 & 6.5 & 11.9 & 7.6 \\
\hline ESP & 14.7 & 19.6 & 13.6 & 11.3 & 19.7 & 12.7 \\
\hline UK & 27.2 & 38.3 & 23.2 & 16.2 & 37.7 & 18.0 \\
\hline USA & 24.5 & 30.9 & 19.1 & 13.8 & 30.7 & 20.0 \\
\hline
\end{tabular}

Wage expressed in USD, 2010. Normalised weights used. Missing values imputed using the Gaussian normal regression imputation method.

Source: own calculations based on data from LIS (wave 8).

Table 3. Variability of hourly wage across countries in our sample - heterogeneity in firm characteristics (industry, size) and type of employment (full-time/part-time)

\begin{tabular}{|c|c|c|c|c|c|c|c|c|}
\hline \multirow{2}{*}{ country } & \multicolumn{3}{|c|}{ Industry } & \multicolumn{2}{c|}{ Part/Full time } & \multicolumn{2}{c|}{$\begin{array}{c}\text { Firm size } \\
\text { (no of emp.) }\end{array}$} & \multicolumn{2}{c|}{$\begin{array}{c}\text { Industry: } \\
\text { Private/Public }\end{array}$} \\
\cline { 2 - 10 } & manuf & services & Part & Full & $<50$ & $>50$ & Private & Public \\
\hline CZE & 6.7 & 7.1 & 6.1 & 6.9 & 6.4 & 7.5 &. &. \\
\hline EST & 5.8 & 6.4 & 6.4 & 6.3 & 5.1 & 6.4 & 6.3 & 6.3 \\
\hline FIN & 27.4 & 25.3 & 23.7 & 25.7 &. &. & 25.7 & 25.1 \\
\hline FRA & 23.8 & 23.5 & 24.2 & 26.5 &. &. & 22.5 & 25.1 \\
\hline DEU & 26.9 & 22.9 & 19.0 & 25.7 & 14.2 & 24.6 & 23.0 & 25.9 \\
\hline GRC & 12.7 & 14.3 & 14.2 & 13.9 & 9.7 & 14.3 & 12.4 & 17.2 \\
\hline IRL & 28.8 & 29.5 & 22.6 & 31.4 & 22.9 & 29.7 & 26.0 & 35.3 \\
\hline LUX & 33.9 & 34.9 & 33.5 & 33.4 & 27.1 & 34.0 & 30.7 & 51.1 \\
\hline MEX & 2.4 & 3.2 & 2.2 & 2.9 & 1.7 & 3.4 & 2.4 & 4.5 \\
\hline SVK & 5.5 & 5.6 & 5.6 & 5.6 & 4.9 & 5.6 &. &. \\
\hline SVN & 8.6 & 9.9 & 6.0 & 9.7 &. &. & 8.8 & 10.2 \\
\hline ESP & 14.2 & 15.2 & 15.0 & 14.7 & 10.3 & 15.1 &. &. \\
\hline UK & 29.7 & 26.5 & 11.0 & 31.8 & 21.6 & 30.1 &. &. \\
\hline USA & 25.2 & 24.4 & 23.2 & 24.7 & 22.1 & 25.5 & 24.4 & 24.8 \\
\hline
\end{tabular}

Wage expressed in USD, 2010. Normalised weights used. Missing values imputed using the Gaussian normal regression imputation method. [.] - the data is unavailable.

Source: own calculations based on data from LIS (wave 8).

The data reported in Table 3 shows the variability of hourly wage across countries with respect to firm characteristics (industry, size) and type of employment 
(full-time/part-time). Also, these features are essential (e.g. wages in big firms are typically higher) which proves that a proper analysis focusing on wages must also take this heterogeneity into account.

\section{Methods of Empirical Analysis}

Our analysis is quantitative, and we rely on econometric methods of estimation to uncover the relationship between our dependent and independent variables. The strategy is similar to that adopted by Baumgarten et al. (2010) and Geishecker, Görg \& Munch (2010): as these authors, we merge micro level data on labour market outcomes with industry-level trade data on production sharing. The first estimated model is based on the specification of Baumgarten et al. (2010) and is as follows (1):

where:

$$
\begin{gathered}
\ln w_{i j c t}=\beta_{0}+\beta X_{i t}+\chi \ln V A_{j c t}+\sum_{e} \theta_{e} \ln F V A_{j c t-1} E d u c_{e i t}+ \\
+\sum_{e} \delta_{e} \ln F V A_{j c t-1} E d u c_{e i t} T_{a s k_{i t}}+D_{j}+D_{c}+D_{j c}+u_{i j c t}
\end{gathered}
$$

Task $_{i t}$ - task index ( 0 - highly routine, low in abstractness and service task importance, 0.5 - low in rou-tine and abstractness, high in service task importance, 1 - low in routine, high in abstractness and service task importance);

$\ln w_{i j c t}-\log$ of the hourly wage of worker $i$ employed in industry $j$ in country $c$ at time $t$;

$X_{i t}$ - set of worker's individual characteristic;

$\ln V A_{j c t}-\log$ of value added of an industry $j$;

$F V A_{j c t-1}$ - lagged log of foreign value added used in industry $j$ and in country $c$;

$E d u c_{e i t}$ - education level \{high, medium, low\};

$D_{j}$ - individual industry effect;

$D_{c}$ - individual country effect;

$D_{j c}$ - industry-country effect;

$u_{i j c t}$ - error term.

Wage $(w)$ is calculated as described in Table 1.The set of worker's individual characteristic $\left(X_{i t}\right)$ refers to his/her: sex, age (age and age $\left.{ }^{2}\right)^{9}$, marital status, living with a partner, having children, education level (low, medium and high, with low education being a reference one - omitted in the regression) and job characteristic (e.g. part time or full time job). These characteristics are present in a standard Mincerian wage model and serve as basic controls of wage determination mechanism. Our crucial variable is called FVA. We include the interaction term between this variable and education $\left(F V A_{j c t-1} E d u c_{e i t}\right)$ to take into account the heterogeneity between the reliance of industries on foreign inputs and wages of workers with different education levels. Finally, the triple interaction term between FVA, education and task measure $\left(F V A_{j c t-1} E_{d u c_{\text {eit }}}\right.$ Task $\left._{i t}\right)$ is included. It allows to capture different reaction of wages within education levels, depending on the task characteristic of worker's occupation.

\footnotetext{
${ }^{9}$ In classical Mincerian approach, the wage depends on education level attained (years of education) and years of on-the-job experience with potentially non-linear impact. We treat age and age squared as the proxy for experience. Unfortunately, given a wide country sample in our analysis, the original microdata from LIS does not provide necessary information on on-the-job experience for individuals from all of the countries.
} 
The marginal effect of FVA depending on the education level e equals to:

$$
\frac{\partial \ln w_{i j c t}}{\partial \ln F V A_{j c t-1}}=\theta_{e}+\delta_{e} \text { Task }_{i t}
$$

The main aim of the estimation (1) is to verify if there is any statistically significant impact of reliance on foreign inputs on wages 'at home'. Our main research hypothesis is that the negative wage effects of international jobs relocation concerns workers who are low educated and/or perform routine tasks. Following Goos et al. (2014), the task index (Task) is derived from the classification of occupations into three categories: $N R$ (low in routine, high in abstractness and service task importance), $L R$ (low in routine and abstractness, high in service task importance) and $H R$ (highly routine, low in abstractness and service task importance). We express Task $_{i t}$ in a numeric format, and it can take one of the three values: 0 for highly routine tasks $(H R), 0.5$ for low in routine and abstractness (LR), high in service task importance and 1 for non-routine tasks $(N R)$. For example, for highly routine tasks the marginal effect of $F V A$ equals simply the coefficient $\theta_{\mathrm{e}}$ while for the non-routine task is the sum of $\theta_{\mathrm{e}}$ and $\delta_{e}$.

The inclusion of industry size (VA) in the model (1) is needed to eliminate the effect of a greater FVA simply due to the higher production. With a view to take into account any other unobserved industrial, country or industry-country heterogeneity (e.g. different wage setting mechanisms in various countries due to different role of labour market institutions) we include three dummies, at the level of industry: $D_{j}$, at the level of country: $D_{c}$ and simultaneous industry-country specific effect: $D_{j c}$.

One potential problem in the model specification (1), is that FVA is likely to be endogenous. Firms are making the strategic choice in which country to locate their activity, what materials to import and from where, and they set wage levels accordingly. However, as pointed out by Baumgarten et al. (2010), in case of a model specification in which we have individual wages and additional information on industry - the endogeneity should not be a problem (individual wages do not affect industry aggregates such as FVA). Nevertheless, we try to eliminate the possibility of endogeneity bias in the estimated model. First, we employ the lag of InFVA - when the information on the use of foreign inputs is included with a time lag, we allow for the wage adjustment to emerge - the similar approach is presented in Ebenstein et al. (2014).

Secondly, we employ instrumental variables (IV) estimation technique in which FVA is treated as endogenous and instrumented by the gravity equation. Such a strategy is used to obtain a precise instrument for FVA trade flow, based on the information on bilateral industry-level trade and a set of industry and country level characteristcs. Such an instrument is more accurate than the one based on simple lag of the dependent variable. Specifically, to obtain the instrument for $F V A$, in the first stage we estimate the following bilateral trade regression (in line with Parteka and Wolszczak-Derlacz, 2015):

$$
\begin{gathered}
F V A_{c j p t}=\beta_{0}+\beta_{1} \ln V A_{c j t}+\beta_{2} \ln V A_{p j t}+\beta_{3} \ln \text { DIST }_{c p}+\beta_{4} \text { Contig }_{c p}+ \\
+\beta_{5} R T A_{c p t}+\beta_{6} \text { Comcur }_{c p}+\beta_{7} \text { Comlang }_{c p}+\beta_{8} \text { Colony }_{c p}+u_{c j p t}
\end{gathered}
$$
where:

$F V A_{\text {cjpt }}$ - foreign value added in industry $\mathrm{j}$, from origin country c (reporter) to partner country $\mathrm{p}$;

$\ln V A_{c j t}-\log$ of value added of industry $\mathrm{j}$ in reporter country c; 
$\ln V A_{p j t}-\log$ of value added of industry $\mathrm{j}$ in partner country $\mathrm{p}$;

$\ln D I S T_{c p}$ - log of the distance between reporter and partner, defined as distance between the major cities in the two countries;

Comcur $_{c p}$ - equals 1 if the two countries have a common land border;

$R T A_{c p t}$ - equals 1 if both countries participate in a common regional trade agreement;

Comcur $_{c p}$ - indicates a dummy variable $=1$ if reporter and partner have a common currency;

Comlang $c_{c p}$ - indicates a dummy variable $=1$ if reporter and partner have a common official language;

Colony $_{c p}$ - indicates a dummy variable $=1$ if reporter and partner have a common colonial past.

The gravity equation is estimated for each industry, using the Poisson Pseudo Maximum Likelihood method - PPML (Silva \& Tenreyro, 2006). The predicted FVA values are summed across all the partner countries (we consider 39 principal partners present in WIOD database and accounting for the majority of world trade), obtaining an overall foreign value export for each industry for a given reporter country. The exercise is repeated for each country from our sample (so $c=1, . ., 14$ ).

Our strategy of model (1) estimation is to use weighted regression with cluster-robust standard errors, where the clusters refer to country-industry pairs. We use normalized personal weights based on the individual-level cross-sectional weights (provided by LIS), which make the sample representative of the total national population or the total population covered $^{10}$. Furthermore, the individual weights are normalized to 10,000 by country. As a result, in our multi-country analysis workers from each country are intended to have the same weight, and the results are not driven by countries with large numbers of observations.

\section{RESULTS AND DISCUSSION}

The result of the regression (1) is presented in Table 4. The first column refers to basic Mincerian wage model only with individual workers' characteristics. All the covariates referring to personal characteristics have the expected signs. Both coefficients referring to age (age in levels and age squared) are statistically significant and with opposite signs: the first one is higher than zero while the age squared is negative which indicates a concave relationship between hourly wages and age. Moreover, males typically earn more than females (on average by $20 \%$ ). While the marital status is not important, workers living with a partner and possessing children have higher wages (respectively by $7 \%$ and by $2.5 \%$ ). Those working part-time on average earn less.

Finally, better-educated workers are characterised by higher wages. The default category is composed of low-educated workers to whom we compare the situation of workers with high and medium education. According to the obtained results, on average workers with medium education earn $20 \%$ more than workers with low education while those with tertiary education by more than $50 \%$. We show that worker' characteristic are important factors in explaining the individual wage differentials.

\footnotetext{
${ }^{10}$ For more about the rules, practices and definitions applied during the harmonization process to ensure consistency over the LIS datasets together with sample-selection and weighting procedures, see: LIS guidelines at: http://www.lisdatacenter.org/wp-content/uploads/our-lis-documentation-harmonisation-guidelines.pdf
} 
Now, when wage differentials between workers are cleaned out of their personal characteristics, we add additional variables. In column (2) of Table 4, we report the results

Table 4. The results of estimation (1)

\begin{tabular}{|c|c|c|c|c|}
\hline \multirow{2}{*}{ Variable / Measure } & \multicolumn{4}{|c|}{ Dep.var: $\ln w_{i j c t}$} \\
\hline & (1) & (2) & (3) & (4) \\
\hline \multirow[t]{2}{*}{$a g e_{i}$} & $0.042^{* * *}$ & $0.043^{* * *}$ & $0.042 * * *$ & $0.040 * * *$ \\
\hline & {$[0.003]$} & {$[0.003]$} & [0.003] & {$[0.003]$} \\
\hline \multirow[t]{2}{*}{$a g e_{i}^{2}$} & $-0.000 * * *$ & $-0.000 * * *$ & $-0.000 * * *$ & $-0.000 * * *$ \\
\hline & {$[0.000]$} & {$[0.000]$} & {$[0.000]$} & {$[0.000]$} \\
\hline \multirow[t]{2}{*}{$\operatorname{sex}_{i}$} & $0.208^{* * *}$ & $0.207^{* * *}$ & $0.207^{* * *}$ & $0.219 * * *$ \\
\hline & {$[0.008]$} & {$[0.008]$} & {$[0.008]$} & {$[0.008]$} \\
\hline \multirow[t]{2}{*}{ marital status $_{i}$} & 0.000 & 0.000 & 0.001 & 0.004 \\
\hline & {$[0.010]$} & {$[0.010]$} & {$[0.010]$} & {$[0.010]$} \\
\hline \multirow[t]{2}{*}{ partner $_{i}$} & $0.073 * * *$ & $0.074 * * *$ & $0.074^{* * *}$ & $0.065^{* * *}$ \\
\hline & {$[0.009]$} & {$[0.009]$} & {$[0.009]$} & {$[0.009]$} \\
\hline \multirow[t]{2}{*}{ children $_{i}$} & $0.025^{* * *}$ & $0.026 * * *$ & $0.026^{* * *}$ & $0.029 * * *$ \\
\hline & {$[0.007]$} & {$[0.007]$} & {$[0.007]$} & {$[0.007]$} \\
\hline \multirow[t]{2}{*}{ part-time $_{i}$} & $-0.207 * * *$ & $-0.209 * * *$ & $-0.207 * * *$ & $-0.184 * * *$ \\
\hline & {$[0.037]$} & {$[0.037]$} & {$[0.037]$} & {$[0.033]$} \\
\hline \multirow[t]{2}{*}{ mededuc $_{i}$} & $0.222 * * *$ & $0.215^{* * *}$ & $0.170^{* * *}$ & $0.168 * * *$ \\
\hline & {$[0.017]$} & {$[0.016]$} & {$[0.035]$} & {$[0.034]$} \\
\hline \multirow[t]{2}{*}{ hieduc $_{i}$} & $0.576^{* * *}$ & $0.566 * * *$ & $0.520^{* * *}$ & $0.514^{* * *}$ \\
\hline & {$[0.023]$} & {$[0.022]$} & {$[0.044]$} & {$[0.042]$} \\
\hline \multirow[t]{2}{*}{$\ln V A_{j c t}$} & & $0.034^{* *}$ & $0.032^{* *}$ & $0.024^{*}$ \\
\hline & & {$[0.015]$} & {$[0.014]$} & {$[0.014]$} \\
\hline \multirow[t]{2}{*}{$\ln F V A_{j c t-1}$} & & -0.019 & & \\
\hline & & {$[0.012]$} & & \\
\hline \multirow[t]{2}{*}{$\operatorname{In} F V A_{j c t-1} H_{i e d u c}$} & & & -0.017 & $-0.094 * * *$ \\
\hline & & & {$[0.012]$} & [0.013] \\
\hline \multirow[t]{2}{*}{$\ln F V A_{j c t-1}$ Mededuc $_{i}$} & & & -0.017 & $-0.038 * * *$ \\
\hline & & & {$[0.012]$} & {$[0.013]$} \\
\hline \multirow[t]{2}{*}{$\ln F V A_{j c t-1}$ Loweduc $_{i}$} & & & $-0.028^{* *}$ & $-0.038^{* * *}$ \\
\hline & & & {$[0.013]$} & [0.013] \\
\hline \multirow[t]{2}{*}{$\ln F V A_{\text {itc-1 }}$ Hieduc $_{i}$ Task $_{i}$} & & & & $0.094^{* * *}$ \\
\hline & & & & {$[0.006]$} \\
\hline \multirow[t]{2}{*}{$\ln F V A_{j c t-1}$ Mededuc $_{i}$ Task $_{i}$} & & & & $0.050^{* * *}$ \\
\hline & & & & {$[0.003]$} \\
\hline \multirow[t]{2}{*}{ InFVA $A_{\text {jct-1Loweduci }}$ Task $_{i}$} & & & & $0.033^{* * *}$ \\
\hline & & & & {$[0.007]$} \\
\hline Under-identification & & 0.000 & 0.000 & 0.000 \\
\hline Weak identification & & 45.293 & 15.990 & 7.851 \\
\hline $\mathrm{N}$ & 165383 & 160944 & 160944 & 156835 \\
\hline
\end{tabular}

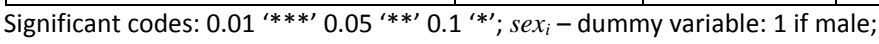

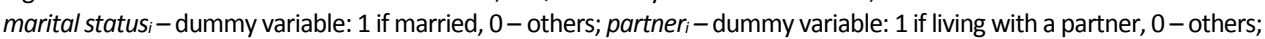
children $_{i}$ - dummy variable: 1 if living with children, 0 - others; part-time ${ }_{-}$-dummy variable: 1 if working part-time, 0 - others; mededuc $_{i}$ - dummy variable: 1 if having medium education, 0 - others;

hieduc $_{i}$ - dummy variable: 1 if having high education, 0 - others.

Regression with cluster-robust standard errors; all specifications include industry and country fixed effects, as well as country-industry panel. The figures reported for the under-identification test are the $p$-values and refer to the Kleibergen-Paap rk LM test statistic. The weak identification test refers to the Kleibergen-Paap Wald rk $F$ statistic test for the presence of weak instruments.

Source: own calculations with data from LIS and WIOD. 
of estimation in which we add the information on the industry size of employment measured by the log of its value added $\left(\ln V A_{j c t}\right)$ and lagged log of its dependence on foreign value added $\left(\operatorname{InFVA} A_{j c t-1}\right)$.

When FVA is included without any interaction (with the assumption that it has the same impact on wages of all workers) - the coefficient is not statistically significant. In the third column of Table 4, we include the interaction term between FVA and education levels. It turns out that there is a negative correlation between FVA and wages in case of workers with the lowest educational attainment (the negative and a statistically significant parameter of $\ln F V A_{j c t-1}$ Loweduc $\left._{i}\right)$.

However, the results of the last regression (Column 4) indicate that apart from taking into account the heterogeneity of workers due to their education level, it is also important to check for the characteristics of tasks their perform. We find that there is a negative correlation between FVA and wages of workers conducting routine tasks (for all the three educational groups: negative parameters of $\operatorname{In} F V A_{j c t-1} H i e d u c_{i}, \operatorname{In} F V A_{j c t}$ ${ }_{1}$ Mededuc $_{i}$ and $\operatorname{In} F V A_{j c t-1}$ Loweduc $\left._{i}\right)$. This effect depends on the task index. For the extreme case of non-routine tasks (i.e. when the task index equals to 1 ), the adverse effect is sustained only in the case of low educated workers $(-0.038+0.033<0)$, while for highly educated and medium educated labour the marginal effect of FVA is either approaching to zero or slightly positive (respectively: $-0.094+0.094$ and $-0.038+0.050$ ).

The final step is to repeat the above process, adding more characteristics on jobs and firms in which workers are employed. In particular, we add information on the firm size. Due to data constraints we divide firms into small (when the number of employees is lower than 50) and big (with number of employees exceeding 50). For some countries we have also information in what kind of a firm given a person is working - private or public. Finally, we augment the model with the information whether a worker has more than one job.

The results of the regression (1) with all the worker's characteristic as in Table 4 (not shown here for the brevity) and additional job characteristic are presented in Table 5. Due to the data constraints, adding job characteristics limits our sample to 7 countries (see Table 3). Analogously, we start with the basic regression without industrial variables and then add the measure of reliance on foreign value added. Similarly to the previous estimation, the coefficient associated with FVA is not statistically significant when the education heterogeneity and task heterogeneity are not taken into account (Column 2). It is negatively correlated with wages of low-educated workers (Column 3) performing different tasks (Column 4). For high- and mediumeducated workers the effect of FVA is materialised only for a given set of tasks: routine but not non-routine. As we can see, the main conclusions are confirmed.

Our main results (i.e. the effect of GVC on wages is conditional upon the skill and task typology, affecting mostly workers performing routine tasks) are in line with other papers using microdata and addressing similar issues (it shall however be noted that they differ from ours due to limited country coverage and traditional measures of offshoring they employ). For example Baumgarten et al. (2013) for the German economy found that the negative wage impact of offshoring is reduced in the case of tasks with high degree of interactivity and non-routines. Similarly, Becker, Ekholm and Muendler (2013) in the analysis of German MNEs shown that onshore workers perform more non-routine and more interactive tasks. Finally, Ebenstein et al. (2014) confirmed that the negative wage effect is 
most pronounced for American workers who perform routine tasks. In general, our results can be placed within the literature underlying negative effects of trade integration on workers performing routine tasks (see Ebenstein, Harrison \& McMillan, 2015 for a recent review). However, the research theme is still disputable, e.g. Blinder and Krueger (2013) argued that more offshorable jobs in the US are typical for educated workers and offshorability does have effects neither on wages nor on the level of employment. Marcolin, Miroudot and Squicciarini (2016) elaborate on the problematic identification of "winners" and "losers" in a GVC context.

Table 5. The results of estimation (1) with additional job and firm characteristics

\begin{tabular}{|c|c|c|c|c|}
\hline \multirow{2}{*}{ Variable / Measure } & \multicolumn{4}{|c|}{ Dep.var: $\ln w_{i j c t}$} \\
\hline & (1) & (2) & (3) & (4) \\
\hline \multirow[t]{2}{*}{ SmallSize $_{i}$} & $-0.269 * * *$ & $-0.262 * * *$ & $-0.261 * * *$ & $-0.261^{* * *}$ \\
\hline & {$[0.026]$} & {$[0.025]$} & {$[0.025]$} & {$[0.026]$} \\
\hline \multirow[t]{2}{*}{ PrivateIndustry $_{i}$} & $-0.094 * * *$ & $-0.103 * * *$ & $-0.105^{* * *}$ & $-0.095 * * *$ \\
\hline & {$[0.028]$} & {$[0.028]$} & [0.029] & {$[0.028]$} \\
\hline \multirow[t]{2}{*}{ SecondJob $_{i}$} & $-0.156 * * *$ & $-0.153^{* * *}$ & $-0.151 * * *$ & $-0.152 * * *$ \\
\hline & {$[0.024]$} & {$[0.025]$} & {$[0.025]$} & {$[0.025]$} \\
\hline \multirow[t]{2}{*}{$\ln V A_{j c t}$} & & $0.057^{* *}$ & $0.057^{* * *}$ & $0.042^{*}$ \\
\hline & & {$[0.023]$} & {$[0.021]$} & {$[0.024]$} \\
\hline \multirow[t]{2}{*}{$\ln F V A_{j c t-1}$} & & -0.030 & & \\
\hline & & {$[0.028]$} & & \\
\hline \multirow[t]{2}{*}{$\operatorname{lnFVA}_{\text {jct-1 }}$ Hieduc $_{i}$} & & & -0.03 & $-0.107 * * *$ \\
\hline & & & [0.019] & {$[0.022]$} \\
\hline \multirow[t]{2}{*}{$\ln F V A_{\text {jct }-I}$ Mededuc $_{i}$} & & & -0.028 & $-0.051 * *$ \\
\hline & & & {$[0.019]$} & {$[0.021]$} \\
\hline \multirow[t]{2}{*}{$\ln F V A_{\text {jct- } 1 \text { Loweduc }}$} & & & $-0.052^{* *}$ & $-0.065 * * *$ \\
\hline & & & {$[0.022]$} & {$[0.022]$} \\
\hline \multirow[t]{2}{*}{$\ln F V A_{j c t-1}$ Hieduc $_{i}$ Task $_{i}$} & & & & $0.092^{* * *}$ \\
\hline & & & & {$[0.008]$} \\
\hline \multirow[t]{2}{*}{$\ln F V A_{\text {jct-I }}$ Mededuc $_{i}$ Task $_{i}$} & & & & $0.053^{* * *}$ \\
\hline & & & & {$[0.004]$} \\
\hline \multirow[t]{2}{*}{$\ln F V A_{\text {jct- }}$ Loweduc $_{i}$ Task $_{i}$} & & & & $0.040 * * *$ \\
\hline & & & & {$[0.012]$} \\
\hline Under-identification & & 0.000 & 0.000 & 0.000 \\
\hline Weak identification & & 19.554 & 11.394 & 11.389 \\
\hline $\mathrm{N}$ & 106820 & 102768 & 102768 & 100990 \\
\hline
\end{tabular}

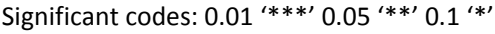

SmallSize $_{\mathrm{i}}$ - dummy variable: 1 for firms with the number of employees $<50,0$ - others,

PrivateIndustry $_{i}$ - dummy variable: 1 if working in private industry, 0 - others,

SecondJob $_{i}$ - dummy variable: 1 if having more than 1 job, 0 - others.

All other individual characteristics as in Table 4 included and not shown for the clarity.

Source: own calculations with data from LIS and WIOD.

\section{CONCLUSIONS}

The main aim of this paper was to present how the heterogeneity of workers, firms, and tasks can be incorporated into empirical international trade analysis. In particular, we provided an empirical example in which we aimed to quantify the effects of trade within GVC and reliance on foreign value added on wages. 
Acknowledging a general lack of this type of studies performed with micro level data and for many countries, we performed an analysis using the rich dataset on workers from 14 countries. The use of microlevel data for workers from many countries is exceptional in the literature on labour market consequences of trade integration. In our study, we have attempted to provide an example of international trade analysis which captures many dimensions of complexity observed in the real world: differences between workers, tasks they perform and firms in which they are employed. We argue that country level or industry level analysis on the international trade-wage nexus is not sufficient.

The first step involved merging microdata on individual workers' characteristic from LIS with industry level information coming from WIOD. Then, we estimated various versions of an augmented Mincerian wage regression. To allow for heterogeneous effects the model has been augmented by inclusion of the measure of foreign value added and its interaction with worker's education level and task typology. Additionally, we instrumented FVA using the gravity approach.

The results indicate that when controlling for individual workers' and job characteristics, there is a negative correlation between FVA and wages. However, the effect is conditional upon the skill and task typology (affecting mostly workers performing routine tasks). For the non-routine tasks, the negative wage effect of FVA is sustained only in the case of low educated workers.

These results have important policy and societal implications: we can interpret them in the light of uneven gains from GVC expansion - some of the workers can indeed be worse off. We have provided quantitative arguments for the debate on the consequences of global production sharing on the labour markets for several economies and going beyond country-specific studies. We have verified our main research hypothesis that the negative wage effects of international jobs relocation concern workers who are low educated and/or perform routine tasks.

We are aware of some limitations of our study. First of all, we took into account total foreign value added from all partner countries, e.g. without a distinction between low and high wage countries. Secondly, our analysis was based only on one wave of LIS microdata. Hence, the suggestions for further research refer mainly to the inclusion of direction of FVA (e.g. by source country) and adding time series approach.

\section{REFERENCES}

Amiti, M., \& Davis, D.R. (2012). Trade, firms, and wages: Theory and evidence. The Review of Economic Studies, 79(1), 1-36.

Amador, J., \& Cabral, S. (2016). Global Value Chains: A Survey of Drivers and Measures. Journal of Economic Surveys, 30(2), 278-301.

Autor, D.H. (2013). The "task approach" to labor markets: an overview. Journal for Labour Market Research, 46(3), 185-199.

Autor, D.H., \& Dorn, D. (2013). The growth of low-skill service jobs and the polarization of the US labor market. The American Economic Review, 103(5), 1553-1597.

Autor, D.H., Dorn, D., \& Hanson, G.H. (2013). The China syndrome: Local labor market effects of import competition in the United States. The American Economic Review, 103(6), 2121-2168. 
Autor, D.H., Dorn, D., \& Hanson, G.H. (2015). Untangling Trade and Technology: Evidence from Local Labour Markets. Economic Journal, 125(584), 621-646.

Baldwin, R., \& Robert-Nicoud, F. (2014). Trade-in-goods and trade-in-tasks: An integrating framework. Journal of International Economics, 92(1), 51-62.

Baumgarten, D., Geishecker, I., \& Görg, H. (2013). Offshoring, tasks, and the skill-wage pattern. European Economic Review, 61, 132-152.

Becker, S.O., Ekholm, K., \& Muendler, M.A. (2013). Offshoring and the onshore composition of tasks and skills. Journal of International Economics, 90(1), 91-106.

Becker, S.O., \& Muendler, M.A. (2015). Trade and tasks: an exploration over three decades in Germany. Economic Policy, 30(84), 589-641.

Bernard, A., Jensen, J., Redding, S., \& Schott, P. (2012). The Empirics of Firm Heterogeneity and International Trade. Annual Review of Economics, 4(1), 283-313.

Blinder, A.S., \& Krueger, A.B. (2013). Alternative Measures of Offshorability: A Survey Approach. Journal of Labor Economics, 31(2 Part 2), S97-S128.

Cortes, G.M. (2016). Where Have the Middle-Wage Workers Gone? A Study of Polarization Using Panel Data. Journal of Labor Economics, 34(1), 63-105.

Dauth, W., Findeisen, S., \& Suedekum, J. (2014). The rise of the East and the Far East: German labor markets and trade integration. Journal of the European Economic Association, 12(6), 1643-1675.

Ebenstein, A., Harrison, A., McMillan, M., \& Phillips, S. (2014). Estimating the impact of trade and offshoring on American workers using the current population surveys. Review of Economics and Statistics, 96(4), 581-595.

Ebenstein, A., Harrison, A., \& McMillan, M. (2015). Why are American workers getting poorer? China, trade and offshoring (NBER Working Paper no. 21027). Cambridge: National Bureau of Economic Research.

Feenstra, R.C. (2016). Advanced international trade: theory and evidence (2nd ed.). Princeton: Princeton University Press.

Fortin, N., \& Lemieux, T. (2016). Inequality and Changes in Task Prices: Within and between Occupation Effects. In L. Cappellari, S.W. Polachek \& K. Tatsiramos (Eds.), Inequality: Causes and Consequences, (pp. 195-226). Bingley: Emerald Group Publishing Limited.

Freeman, R.B. (1995). Are your wages set in Beijing?. The Journal of Economic Perspectives, 9(3), 15-32.

Geishecker, I., Görg, H., \& Munch, J.R. (2010). Do labour market institutions matter? Micro-level wage effects of international outsourcing in three European countries. Review of World Economics, 146(1), 179-198.

Geishecker, I., \& Görg, H. (2013). Services offshoring and wages: Evidence from micro data. Oxford Economic Papers, 65(1), 124-146.

Goos, M., Manning, A., \& Salomons, A. (2014). Explaining job polarization: Routine-biased technological change and offshoring. The American Economic Review, 104(8), 2509-2526.

Grossman, G.M., \& Rossi-Hansberg, E. (2008). Trading tasks: A simple theory of offshoring. The American Economic Review, 98(5), 1978-1997.

Grossman, G.M. (2013). Heterogeneous workers and international trade. Review of World Economics, 149(2), 211-245.

Harrison, A., \& McMillan, M. (2011). Offshoring jobs? Multinationals and US manufacturing employment. Review of Economics and Statistics, 93(3), 857-875.

Heckman, J.J., Lochner, L.J., \& Todd, P.E. (2006). Earnings functions, rates of return and treatment effects: The Mincer equation and beyond. Handbook of the Economics of Education, 1, 307-458. 
Helpman, E., Melitz, M., \& Rubinstein, Y. (2008). Estimating Trade Flows: Trading Partners and Trading Volumes. The Quarterly Journal of Economics, 123(2), 441-487.

Hummels, D., Jørgensen, R., Munch, J., \& Xiang, C. (2014). The wage effects of offshoring: Evidence from Danish matched worker-firm data. The American Economic Review, 104(6), 1597-1629.

Los, B., Timmer, M.P., \& Vries, G.J. (2015). How global are global value chains? A new approach to measure international fragmentation. Journal of Regional Science, 55(1), 66-92.

Marcolin, L., Miroudot, S., \& Squicciarini, M. (2016). Routine jobs, employment and technological innovation in global value chains. OECD Science, Technology and Industry Working Papers, 1.

Melitz, M.J. (2003). The impact of trade on intra-industry reallocations and aggregate industry productivity. Econometrica, 71(6), 1695-1725.

Melitz, M.J., \& Redding, S.J. (2014). Heterogeneous Firms and Trade. In G. Gopinath, E. Helpman \& K. Rogoff (Eds.), Handbook of International Economics. North Holland.

Olczyk, M., \& Kordalska, A. (2016). Gross Export versus Export in Value Added: determinants and policy implications for manufacturing sectors in selected CEE countries. Eastern European Economics, doi:10.1080/00128775.2016.1254564

Parteka, A., \& Wolszczak-Derlacz, J. (2015). Integrated sectors-diversified earnings: the (missing) impact of offshoring on wages and wage convergence in the EU27. The Journal of Economic Inequality, 13(3), 325-350.

Quast, B., \& Kummritz, V. (2015). Decompr: Global Value Chain Decomposition in R (CTEI Working Papers, 1-17). Geneva: Center for the Trade and Economic Integration.

Silva, J.M.C.S., \& Tenreyro, S. (2006, November). The log of gravity. The Review of Economics and Statistics, 88, 641-658.

Timmer, M.P., Dietzenbacher, E., Los, B., Stehrer, R., \& Vries, G.J. (2015). An illustrated user guide to the world input-output database: the case of global automotive production. Review of International Economics, 23(3), 575-605.

Yeaple, S.R. (2005). A simple model of firm heterogeneity, international trade, and wages. Journal of International Economics, 65(1), 1-20.

Wagner, J. (2012). International trade and firm performance: a survey of empirical studies since 2006. Review of World Economics, 148(2), 235-267.

Wang, Z., Wei, S.-J., \& Zhu, K. (2013). Quantifying International Production Sharing At the Bilateral and Sector Levels (NBER Working Paper 19667). Cambridge: National Bureau of Economic Research.

Wolszczak-Derlacz, J., \& Parteka, A. (2016). The effects of offshoring to low-wage countries on domestic wages. A worldwide industrial analysis. Empirica. Journal of European Economics, doi: 10.1007/s10663-016-9352-4

Wood, A. (1995). How trade hurt unskilled workers. The Journal of Economic Perspectives, 9(3), 57-80. 


\section{Authors}

The contribution share of authors is equal and amounted to $50 \%$ each of them.

\section{Aleksandra Parteka}

Associate professor (with habilitation in economics) at the Faculty of Management and Economics, Gdansk University of Technology (Gdansk, Poland). Her research interests include: international trade, economic integration, trade-labor market interactions, productivity and efficiency analysis.

Correspondence to: Gdansk University of Technology, Faculty of Management and Economics, Narutowicza 11/12, 80-233 Gdansk, Poland; e-mail: aparteka@zie.pg.gda.pl

\section{Joanna Wolszczak-Derlacz}

Associate professor at Gdańsk University of Technology, Faculty of Management and Economics. Her research interests include theory and empirics of wage and price convergence, economic growth, productivity and efficiency of higher education institutions.

Correspondence to: Gdansk University of Technology, Faculty of Management and Economics, Narutowicza 11/12, 80-233 Gdansk, Poland; e-mail: jwo@zie.pg.gda.pl

\section{Acknowledgements and Financial Disclosure}

The research has been conducted within the project financed by the National Science Centre, Poland (Narodowe Centrum Nauki - NCN) - decision numer DEC-2015/19/B/HS4/02884. The authors would like to thank the participant of the Conference organized by Department of Foreign Trade of Cracow University of Economics, Cracow 7th Nov 2017 and the anonymous referees for their useful comments, which allowed to increase the value of this article.

\section{Copyright and License}

This article is published under the terms of the Creative Commons

Attribution - NoDerivs (CC BY- ND 4.0) License http://creativecommons.org/licenses/by-nd/4.0/

Published by the Centre for Strategic and International Entrepreneurship - Krakow, Poland 
